\title{
CD11B Expressing Cell Count
}

National Cancer Institute

\section{Source}

National Cancer Institute. CD11B Expressing Cell Count. NCI Thesaurus. Code C105440.

The determination of the amount of the CD11b expressing cells in a sample. 